Karolina Prykowka-Michalak (D) https://orcid.org/0000-0003-1560-1645

Uniwersytet Łódzki, Wydział Filologiczny

e-mail: karolina.prykowska@uni.lodz.pl

\title{
Kryzys publiczności w teatrze niemieckim?
}

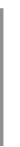

\section{Abstract \\ Crisis of the Audience in German Theater?}

Research indicates that German theater is struggling with an audience crisis demonstrated by a decrease in audience attendance. The aim of the article is to present various positions indicating an audience crisis in German theaters and their analysis in the context of the latest concepts of audience research. In modern German theater, two orientations clash, one focusing on the art itself, the other leaning towards the audience and its development. Can you find a compromise between such extreme positions? Does the crisis of the public in German theaters refer only to economic factors? Or it is worth, as I indicate in this text, to analyze the situation of the progressive development and responsibility of the audience of some German theaters, examples are theaters in Halle, Weimar and Berlin.

Keywords: German theater, theater audience, audience research

Słowa kluczowe: teatr niemiecki, publiczność teatralna, badania publiczności

\section{Wprowadzenie}

Kryzys w teatrze niemieckim to pojęcie często powracające w wielu różnych wymiarach.

Kryzys lat siedemdziesiątych XX wielu był kryzysem programowym - efektem braku reakcji teatrów (postrzeganych jako skostniale mieszczańskie instytucje) na nasilające się ruchy polityczne związane z protestami studenckimi końca lat sześćdziesiątych. Później w latach osiemdziesiątych nastał kryzys finansowy. Sytuacja wielu teatrów publicznych w zachodnich Niemczech była trudna, duże 
wielodziałowe teatry na przykład w Nadrenii Północnej-Westfalii poddawano rekonstrukcji, zmniejszała się liczba teatrów jako samodzielnych organizacji, ale przybywało miejsc, gdzie wystawiano spektakle. Po zjednoczeniu Niemiec zmienił się krajobraz teatralny we wschodniej części kraju, zamknięto teatry w mniejszych miastach (Frankfurt, Cottbus) ${ }^{1}$.

W XXI wieku wspomnieć należy polemikę pod hasłem „zawał kultury” (Kulturinfrakt) zakończoną kontrowersyjną publikacją czterech ekspertów do spraw kultury [Haselbach et al. 2012] wskazujących na problem nadprodukcji artystycznej oraz swoistą homogenizację programów, a w rezultacie prezentację „wszędzie tego samego". Echa słyszalne są także teraz, gdy ponownie analizuje się nowe perspektywy rozwoju teatrów publicznych. Badania publiczności teatralnej prowadzone przez Patricka Föhla i Damaris Nübel [Föhl, Nübel 2016] wskazują na kryzys uczestnictwa młodych ludzi, nawet tych z wyższym wykształceniem. Okazuje się bowiem, że teatr jest miejscem, które z powodu trudnych oficjalnych kodów kulturowych ich odstrasza [Föhl, Nübel 2016: 211].

Jedną z tez dość obszernej i wielowątkowej publikacji Thomasa Schmidta ${ }^{2}$ z 2016 roku Theater, Krise und Reform. Eine Kritik des deutschen Theatersystems [Teatr, kryzys i reforma. Krytyka niemieckiego systemu organizacji teatrów] jest, upadek wielu teatrów publicznych w Niemczech, który nastąpi w ciągu najbliższych czterdziestu lat, a rozpocznie się po 2020 roku, kiedy wygaśnie wsparcie finansowe dla wschodniej części tak zwanego Solidarpakt II. Schmidt wykazuje, że liczba widzów spada, a wzrasta liczba produkcji teatralnych, co w rezultacie doprowadzi do załamania systemu subwencjonowania teatrów.

Celem tego artykułu jest przedstawienie różnych stanowisk wskazujących na kryzys publiczności w teatrach niemieckich oraz ich analiza w kontekście najnowszych koncepcji badań publiczności.

${ }^{1}$ Ostatecznie bilans rekonstrukcji po zjednoczeniu Niemiec wyglądał następująco: w 1991/1992 były 154 publiczne teatry, łącznie 462 miejsca gry, co dawało razem 204328 miejsc na widowni.

W 2000/2001 było już tylko 149 teatrów z 728 miejscami do gry i 260000 miejsc na widowni. W 2010/2011 pozostało tylko 140 teatrów z 890 miejscami gry i jeszcze większą liczbą miejsc na widowni (278 297). Zatem w zasadzie do 2010 roku potrojono liczbę miejsca gry, a publiczność pozostała na tym samym poziomie ok. 5000000.

2 Thomas Schmidt jest profesorem i dyrektorem programu studiów zarząadzania teatrem i zarządzania orkiestrą Na Uniwersytecie we Frankfurcie oraz członkiem Department of Visual and Environmental Studies na Uniwersytecie Harvarda. Od 2003 do 2011 roku był dyrektorem zarządzającym, a następnie dyrektorem generalnym Deutschen Nationaltheaters Weimar (Teatru Narodowego w Weimarze). 


\section{Klasyczne formy kultury}

W Niemczech teatry były i są instytucjami kultury o dużym znaczeniu społecznym, gdyż wydaje się na nie znaczne środki publiczne³. Są zaliczane do instytucji kultury klasycznej (klassische Kulturinstitutionen/klassische Kultureinrichtungen) [Mandel, 2016/2017] i zajmują czołowe miejsce w niemieckiej polityce kulturalnej, gdyż jest to polityka zorientowana głównie na sztukę profesjonalną prezentowaną przez instytucje publiczne [Allensbach 1991; Mandel 2016/2017].

Tak zwane klasyczne formy i instytucje, takie jak teatr, opera, są często głównymi aktorami w debatach społeczno-politycznych chociaż duża część populacji wcale do nich nie chodzi. Badania wykazują, że większość odwiedzających teatry niemieckie ma co najmniej dyplom ukończenia szkoły średniej lub uniwersytecki także młodsza publiczność reprezentuje wysoki poziom wykształcenia. Jak zauważa Stefanie Herrmann, „[c] hociaż integracyjny i wzmacniający potencjał kultury jest dobrze znany, pozostaje ona przestrzenią uprzywilejowaną, która utrwala istniejące relacje władzy i odtwarza nierówności społeczne" [Herrmann 2018].

Sytuacja ta jest wynikiem wyboru, jakiego dokonuje władza, menedżerowie i intendenci teatrów oraz finalnie samo społeczeństwo. Jeśli bowiem opowiemy się za podejściem „zorientowanym na sztukę”, a nie na odbiorców, to rozwijać się będą twórcy pod opieką klasycznych instytucji kultury, zwiększy się produkcja artystyczna - bez gwarancji, że ktoś będzie ją jeszcze oglądał - czyli popyt na sztukę będzie malał. Taki problem był już w Niemczech dyskutowany przy okazji publikacji „zawał kultury”.

Jeśli jednak skłonimy się ku orientacji odbiorcy, to znaczy stałemu rozszerzaniu kręgu widzów, to czeka nas długa walka o zmiany w strukturach samych instytucji, systemie organizacji teatrów oraz mentalności twórców. Działania idące w tym kierunku zostały podjęte przez kilka teatrów, są to jednak ciągle pojedyncze przypadki opisywane w publikacjach i stawiane za wzór [Mandel 2013: 137-152].

Na jednej z ostatnich konferencji naukowych zatytułowanej „Mythos Publikum”, (Berlin, grudzień 2017) poświęconej badaniom publiczności, dobitnie wybrzmiało to, co do tej pory było przemilczane:

klasyczne instytucje kultury czynią konsumpcję swojej oferty praktyką elitarną, co popiera większość społeczeństwa, akceptując ich tradycyjne programy artystyczne oraz odmawiając uczestnictwa w alternatywnych formach. Badania jakościowe zorientowane na zrozumienie indywidualnych systemów wartości, wyborów, doświadczeń, dyskomfortu tzw. (nie)odwiedzających, mogłyby przynieść jakieś efekty [Herrmann, 2018].

${ }^{3}$ Urzędy statystyczne krajów związkowych w Kulturfinanzbericht w 2018 roku podały, że w 2015 roku wydatki publiczne na teatr i muzykę wyniosły 2,0 mld euro. W dużej mierze 54,4\% partycypowały w tym gminy. Kraje związkowe przekazały odpowiednio 1,6 mld euro, czyli 44,6\%, a wydatki rządu federalnego wyniosły $33,7 \mathrm{mln}$ euro, czyli około $0,9 \%$. 
Nie gwarantuje to jednak, że nawet najbardziej wiarygodne wyniki badań będą w stanie zmienić tradycyjne struktury kształtowane przez wiele lat.

Ciągłe balansowanie między sztuką a potrzebą zaspokojenia publiczności jest immanentną cechą teatru niemieckiego, nierozwiązaną od XVIII wieku. Gdy w 1784 roku Friedrich Schiller pisał w przedmowie do Teatr jako instytucja moralna (Die Schaubühne als eine moralische Anstalt betrachtet) rozpoczynał tym samym debatę teatralną wskazującą na potrzebę nawiązania lepszego kontaktu z publicznością. Chodziło o aktywne, refleksyjne oglądanie i wyciąganie wniosków, a nie tylko o popularną rozrywkę. Teatr taki miał więc łączyć wiele funkcji, będąc „instytucją, w której przyjemność idzie w parze z nauką, odpoczynek z wysiłkiem, rozrywka z kształceniem" [Dobijanka-Witczakowa oprac. ca 1996: 154]. Ten osiemnastowieczny manifest Schillera, aby teatr „miał się stać instytucją umacniającą kulturalną tożsamość i jedność niemiecką, zapewniając zarazem Niemcom poczesne miejsce w ogólnoludzkiej wspólnocie moralno-estetycznej” [Janion, Żmigrodzka 1998: 70] był elementem szerszego planu, dziś nazwalibyśmy go audience development - rozwojem publiczności. Zauważmy od razu, że w osiemnastowiecznym teatrze nie chodziło o wskaźniki ilościowe, bo inne mechanizmy sterowały teatrem, był rozrywką mieszczaństwa i starano się sprostać jego oczekiwaniom ${ }^{4}$.

Z tradycji Schillerowskiej zostało w Niemczech coś, co nazywamy Kulturbildung - czyli kształceniem przez uczestnictwo w kulturze, obcowanie z wytworami kultury i sztuki. Chodzi o stałe programy skierowane do uczniów, różnych szczebli kształcenia, w przypadku teatru całą złożoną dziedzinę, jaką jest pedagogika teatralna oraz pokrewne jej, takie jak mediacja kulturalna, edukacja kulturalna i rozwój odbiorców. Wszystkie te hasłowo wymienione obszary interwencji w ostatnich latach stały się głównymi zasadami polityki kulturalnej większości krajów związkowych.

W Niemczech polityka kulturalna jest domeną wewnętrznej polityki landów, istnieją jednak pewne przesłanki wspólnej linii, zostały one ustanowione już w latach siedemdziesiątych XX wieku. Tak zwana nowa polityka kulturalna wprowadzona w zachodnich Niemczech kontynuowana była także po zjednoczeniu. Jej głównym założeniem była zasada „kultura dla wszystkich” ukształtowana przez socjaldemokratyczną opcję polityczną. Teatry publiczne otrzymały więc ważne zadanie upowszechnienia swojej oferty artystycznej, tak aby mogła trafić do szerokiego kręgu odbiorców. Zadanie to było jednak dla wielu teatrów zbyt trudne do wykonania, a co najważniejsze jego efekty nigdy nie były egzekwowane. Szczytne idee pozostają do dziś na papierze, a instrumenty wykonawcze (subwencjonowanie instytucji, kasa chorych dla artystów) rozwijają elitarność.

${ }^{4}$ Dowodem w tej sprawie jest Rozmowa wstępna w teatrze stanowiąca wstęp do Fausta J.W. Goethego, gdzie Dyrektor zastanawia się, „czy się impreza powiedzie”, obawia się bowiem o to, czy zdoła „tłumom dogodzić” [Goethe 1953: s. 7]. 


\section{Polityka a instytucje kultury}

Obecnie w polityce kulturalnej doprecyzowano pojęcie „kultura dla wszystkich” i propagowana jest idea, zgodnie z którą kultura ma stać się przestrzenią dialogu interkulturowego. Założeniem jest tworzenie ofert programowych skupiających się wokół różnic multikulturowego społeczeństwa, które to staną się produktywne dzięki sztuce i stworzą nowe tożsamości „transkulturowe” [Mandel 2016/2017]. Presja polityczna na tego typu aktywności jest odczuwalna, ale większość teatrów jest powściągliwa w planowaniu takich działań, a stoją za nimi tak ważne argumenty, jak: konstytucyjnie chroniona wolność sztuki jako zasada instytucjonalnego wsparcia i ochrony twórców oraz zasady federalizmu politycznego gwarantujące, że państwo nie ingeruje w dziedzinę sztuki z obawy, przed jej funkcjonalizacją np. dla polityczno-propagandowych celów. Problem braku efektów w realizacji założeń polityki kulturalnej prowadzi do takich decyzji władzy, jak radykalna zmiana przywództwa w wybranej instytucji kultury oraz wprowadzenie innej linii programowej. Niestety na razie przykłady z ostatnich lat wskazują, że takie działania władz lokalnych nie zyskują uznania $\mathrm{w}$ środowisku teatralnym oraz wśród publiczności. Wymienić tu należy spór o Volksbühne, o którym piszę także poniżej [por. Prykowska-Michalak 2018]; fiasko dyrekcji Armina Petrasa w Stuttgarcie czy załamanie linii programowej monachijskiego Kammerspiele w czasie dyrekcji Matthiasa Lilienthala.

\section{Rozwój publiczności}

Świadomość konieczności rozwoju publiczności w standardach interkulturowych, o których pisała Mandel [2013] istnieje, mimo że diagnoza tej badaczki mówi o tym, że dopiero gdy

osoby odpowiedzialne za sztukę, które w hierarchii instytucji publicznych - teatrów wyraźnie przewyższają osoby odpowiedzialne za marketing, uznają pracę $\mathrm{z}$ nowymi odbiorcami za artystycznie cenną, a poprzez to uzyskają pozytywną ocenę w ponadregionalnej prasie branżowej, będzie można oczekiwać pozytywnej decyzji kierownictwa w celu bardziej skutecznego otwarcia instytucji na interesy nowych grup użytkowników [Mandel 2016/2017]

Problem więc tkwi w samych strukturach oraz systemie organizacji teatrów, który słabo reaguje na zmiany społeczne, demograficzne i inne. Społeczeństwo niemieckie zmienia się w wielu wymiarach. Andreas Reckwitz pisze o zmianie paradygmatu ze społeczeństwa powszechnego na społeczeństwo indywidualności (Die Gesellschaft der Singularitäten) [Reckwitz 2018], co ma wpływ także na produkcję teatralną. Główne tezy z pracy Reckwitza zostały wykorzystane także w ocenie rynku teatralnego, który to w myśl jego badań rozwijać się będzie jako rynek produkujący 
jednorazowe, osobliwe wydarzenia: „Każda produkcja teatralna, która będzie chciała odnieść sukces, musi tej osobliwości poszukiwać oraz potem zostać za taką uznana, aby przyciągnąć uwagę publiczności” [Theater und Theaterkritik 2018]. Czyli nastąpić może jeszcze głębsza izolacja i atomizacja publiczności tych osobliwych, jednorazowych wydarzeń od coraz większej grupy (nie)uczestniczących z powodów niedostosowania ofert programowych do ich oczekiwań.

Spada frekwencja na widowni, więc spada liczba biletów sprzedawanych na spektakle. Jest to jednak pojęcie dość względne, aby je dobrze zinterpretować, trzeba wziąć pod uwagę wiele specyficznych czynników niemieckiego systemu organizacji teatrów. Podstawową pułapką przy jego ocenie jest bowiem tendencja do pewnych ujednoliceń i budowania diagnoz dla całego kraju, którego federalna struktura każe nam przyjrzeć się poszczególnym krajom związkowym, panującej tam opcji politycznej, polityce kulturalnej i sytuacji ekonomicznej.

Niemiecki system charakteryzuje się dużą dywersyfikacją kompetencji w dziedzinie polityki kulturalnej. Rozkładają się one między kilka różnych struktur państwowych, podstawową są ministerstwa kultury w krajach związkowych. W zasadzie istnieje więc tyle modeli polityki kulturalnej, ile krajów związkowych. Wiele kategorii dotyczących niemieckiej polityki kulturalnej, systemu organizacji teatrów czy modeli rozwoju widowni ma więc charakter heterogeniczny. Cecha ta jest zatem dominująca i przekłada się na wiele innych aspektów życia teatralnego w Niemczech [Prykowska-Michalak 2016: 101-117].

\section{Statystyki}

Skoro warunki pracy i rozwoju teatru są tak różne, skąd wiemy o spadającej frekwencji? Pewne ujednolicone dla całego kraju, systemy i modele statystyczne opracowywane zostały przez organizacje trzeciego sektora Deutscher Bühnenverein - DBV (Niemiecki Związek Scen). Związek odwołuje się do dziewiętnastowiecznej tradycji ochrony praw właścicieli scen miejskich, dziś jest to organizacja, która między innymi wprowadziła spójną metodę obliczania wartości dotacji publicznej, przyznawanej teatrom przez władze regionalne lub miejskie. Jest to algorytm, którego dane wejściowe stanowią sumę dotacji, kwotę przychodów własnych, dzieloną przez sumę kosztów oraz liczbę widzów, co wskazuje na wartość, jaką dotowany jest jeden bilet teatralny. Podstawowym kryterium przy ocenie organizacyjno-finansowej teatru stosowanej przez DBV jest liczba widzów, wykazywana w liczbach rzeczywistych, a także jako wartość procentowa wskazująca na frekwencję. To właśnie na podstawie analizy raportów DBV badacze niemieccy odnotowali ogólny spadek liczby widzów niemieckich teatrów. Dane wskazują, że jeszcze w sezonie 1991/1992 teatry odwiedziło 22044216 widzów, dziewięć lat później (sezon 2010/2011) było już tylko 20957 551, a więc mniej o ponad $1 \mathrm{mln}$ widzów, co stanowi prawie pięcioprocentowy 
spadek frekwencji. Według kolejnego raportu DBV wydanego w 2015 roku można zauważyć, że w sezonie 2013/2014 sytuacja ustabilizowała się, gdyż całkowita liczba widzów znów wyniosła 20973 949, co przekłada się na wskaźnik 76\%-78\% zapełnienia miejsc na widowni.

Raport z sezonu teatralnego 2017/2018 wskazuje na łączną liczbę widzów wynoszącą 20446 304; jest to spadek w stosunku do wcześniejszego sezonu o 600000 widzów.

Spróbujmy zbudować jednak szerszą perspektywę w analizie tych danych, poczynając od komentarza Marca Grandmontagne’a, dyrektora zarządzającego DBV, który uważa, że wahania liczby sprzedanych biletów w niemieckich teatrach nie są niczym niezwykłym. Przez 15 sezonów liczba odwiedzających raz rośnie, raz maleje, gdyż w ostatnich latach prowadzono wiele remontów, ograniczono liczbę miejsc na widowniach, ale to, co najcenniejsze, zauważa Grandmontagne, w ostatnich latach rośnie liczba ofert skierowanych na dialog z publicznością i jej edukację - czyli zaczynają działać strategie rozwoju publiczności. Dane dotyczące frekwencji w czasie tak zwanych innych wydarzeń wskazują na około ośmioprocentowy wzrost, także uczestnictwo w „teatralnym programie ramowym” wzrosło o ponad pięć procent [http://www.buehnenverein.de, odczyt: 19.08.2019]. „Inne wydarzenia” to przede wszystkim spotkania, mediacje z publicznością, wprowadzenia przed spektaklami czy dyskusje panelowe organizowane w ramach bardzo dobrze rozwiniętej w Niemczech pedagogiki teatru skierowanej precyzyjnie na rozwój publiczności właśnie tej sceny. Ramowy program teatralny opracowany zazwyczaj na cały sezon zawiera propozycje różnych aktywności towarzyszących spektaklom, są wśród nich: odczyty, próby czytane, czytania performatywne, wystawy i performanse. Trudno tu o jakiekolwiek ujednolicenia, gdyż oferta programów ramowych jest dostosowana do danego teatru, jego doświadczeń w pracy z publicznością.

Heterogeniczność ujawnia się na wielu polach, po pierwsze w najróżniejszych modelach teatrów. Statystyki DBV wyróżniają osiem różnych typów widowisk, są to: opera, taniec, operetka, musical, dramat, teatr dla młodzieży i dzieci, teatr lalkowy (Figurentheater) oraz koncerty, wśród których dominują przedstawienia/wydarzenia muzyczne. Kultura muzyczna, a co za tym idzie, uczestnictwo w spektaklach operowych, operetkowych musicalowych od lat jest na bardzo dobrym poziomie. O popularności tej dziedziny sztuki świadczą przede wszystkim wyniki frekwencyjne niemieckich scen stanowiące odpowiedź na światowy poziom wykonań artystycznych. Na ponad 12 tysięcy przedstawień muzycznych odnotowano w sezonie 2013/2014 7,7 mln widzów (w sezonie 2010/2011 było 7,6 mln), w porównaniu ze spektaklami w teatrach dramatycznych, gdzie liczba widzów w tym samym sezonie osiągnęła 5,3 mln, zainteresowanie publiczności teatrem muzycznym jest imponujące. Wskazuje ono także na specyfikę niemieckiego systemu teatralnego na tle innych europejskich i światowych systemów, dominacja teatru muzycznego przekłada się także na wartości ekonomiczne. Badania Deutsches Musikinformationszentrum 
z 2013 roku wskazują, że Niemcy mają znaczący (około 1/3) udział w globalnym rynku operowym [http://www.miz.org/statistiken/konzerte-musiktheater-s1511\#3; odczyt: 19.08.2019].

A więc wspomniany wyżej kryzys publiczności nie dotyczy pięciu z ośmiu typów badanych teatrów. Ma związek głównie z tak zwanym teatrem mówionym Sprechtheater albo Schauspiel, czyli teatrem dramatycznym. Warto także zauważyć, że kryzysowi nie poddają się teatry kierujące swoją ofertę do grup młodzieżowych i lalkowych, bo te zapełniają się w $98 \%$.

Zastanawiając się nad fenomenem czy też specyfiką publiczności w niemieckich teatrach, należy wskazać, że jej cechą charakterystyczną jest odwzorowanie heterogeniczności modelu federacyjnego. Nie ma jednego narodowego teatru niemieckiego, więc nie ma zbiorowej odpowiedzialności za teatr, jest natomiast silne lokalne przywiązanie do teatru, który należy do danej społeczności, mimo że społeczność ta w statystykach nie jest ujmowana w liczbach, to jej zaangażowanie w sprawy teatru jest znaczące. Świadczy to o wysoko rozwiniętym społeczeństwie obywatelskim zdolnym do podejmowania efektywnych działań. Przytoczone poniżej przykłady oddolnych inicjatyw mających na celu ratowanie lokalnych scen wydarzyły się na początku XXI wieku, ostatni przypadek to historia rozpoczęta w 2017. Czyli cały czas te same pobudki; konflikty na linii władza - instytucja kultury, są w stanie zaktywizować trzeciego partnera, czyli społeczność lokalną.

\section{Przykłady zaangażowania spoleczności lokalnej}

Przykładów potwierdzających takie działania jest w Niemczech kilka. Jednym z nich jest teatr w Halle, mieście liczącym ponad 200 tysięcy mieszkańców we wschodniej części Niemiec. Na początku XXI wieku powstał problem nierentowności wielodziałowego teatru miejskiego. Dział Thalia Theater - teatr grający dla młodszej widowni miał zostać zamknięty, aby ratować pozostałe części: operę oraz orkiestrę miejską. Spółka, która powstała w 2003 roku, miała na celu optymalizację działań i ratowanie miejskich teatrów, które były zagrożone likwidacją. Zaplanowano połączenie dotychczasowego teatru miejskiego, Staatskappele (miejskiej orkiestry), Neues Theater (teatru dramatycznego), Puppen Theater (teatru lakowego) oraz Thalia Theater (teatru dla dzieci i młodzieży). Po fuzji okazało się, że we wszystkich jednostkach - poza teatrem dla dzieci i młodzieży - Thalia Theater, znacząco spadła frekwencja i powstał znaczący niedobór w budżecie spółki, który miał zostać pokryty pieniędzmi odzyskanymi z likwidacji jednego z działów. Paradoksalnie wybrano właśnie teatr dla dzieci i młodzieży - Thalia Theater. Mieszkańcy Halle opowiedzieli się jednak za utrzymaniem tej organizacji. Powołano także fundację Förderverein Pro Halle, która przy wsparciu lokalnych przedsiębiorstw działa na rzecz rozwoju miasta. W wyniku lokalnych działań Thalia Theater gra do dziś i jest najbardziej 
rentowną częścią powołanego w 2009 roku kombinatu TOO GmbH Halle (Theater, Oper, Orchester). Dziś miasto promuje się jako ośrodek kultury i sztuki oferujący pięć różnych działów teatru i muzyki, które współpracują z sobą.

Innym przykładem zaangażowania publiczności w ochronę ich teatru był słynny i opisywany wielokrotnie przypadek teatru weimarskiego. Fundacja Niemieckiego Narodowego Teatru i Narodowej Orkiestry w Weimarze (Stiftung Deutsches Nationaltheater und Staatskapelle Weimar) założona została w 2002 roku, kiedy powstało zagrożenie likwidacją Deutsches National Theater Weimar. Władze kraju związkowego chciały rozwiązać ten teatr, ewentualnie doprowadzić do połączenia go z teatrem w Erfurcie. Mieszkańcy nie tylko Weimaru, ale i całej Turyngii, protestowali przeciwko zamknięciu jednego z najbardziej znanych historycznych teatrów Niemiec, założyli fundację wspierającą go i dzięki jej zaangażowaniu teatr zdołano uratować. Fundacja wspierająca teatr jest jednocześnie udziałowcem spółki Deutsches National Theater Weimar. W latach 2003-2008, kiedy Teatrem Narodowym w Weimarze kierował Thomas Schmidt, wprowadzono w nim tak zwany weimarski model zarządzania teatrem. Polegał on na współpracy całego zespołu zatrudnionego w teatrze i ich wspólnej decyzji o zamrożeniu dodatków do wynagrodzeń wynikających ze zmian taryfowych, co pozwoliło uzupełnić niedobory finansowe w kasie spółki i dzięki temu zachować miejsca pracy oraz zoptymalizować produkcję artystyczną.

Ostatni przykład zaangażowania publiczności w obronę teatru jest trudny w jednoznacznej interpretacji. Chodzi o odwołanie Franka Castorfa z funkcji dyrektora Volksbühne z początkiem sezonu 2017/2018. Po 25 latach Castorf odszedł z teatru na Placu Róży Luksemburg z powodu nowej wizji rozwoju tej sceny opracowanej w referacie kultury Senatu Berlina [por. Prykowska-Michalak 2016; 2017]. Według Birgit Mandel była to szansa na zmianę programu artystycznego i ogólna radykalna reorientacja misji i celów tej placówki na różnorodność: „Wizji tej przeciwstawili się sami twórcy obawiający się rozpadu niemieckiej tradycji teatralnej i klasycznego kanonu teatralnego" [Mandel 2016/2017]. Spory związane z nową dyrekcją - Chrisa Dercona (wcześniej dyrektora Tate Modern w Londynie) i jego wizją odnowy tego teatru toczyły się przez trzy sezony. Poza wypowiedziami ludzi teatru, reżyserów, aktorów protestami zespołu na uwagę zasługuje odważna postawa publiczności. We wrześniu 2017 pod listem protestacyjnym skierowanym do berlińskiego Senatu, mającym na celu zatrzymać zmiany w Volskbühne, podpisało się, jak podaje „Berliner Zeitung” 40000 osób. List ten jednak nie przyniósł żadnego skutku, bo Castorf ostatecznie odszedł z Volksbühne. Publiczność pokazała jednak swoją siłę, bojkotując teatr Dercona - ostatecznie odwołanego ze stanowiska dyrektora po niespełna siedmiu miesiącach od inauguracji sezonu [Prykowska-Michalak 2018]. Publiczność to przecież wyborcy, dlatego nowy senator do spraw kultury sprawujący swój urząd od 2018 roku, Klaus Lederer reprezentujący partię Die Linke, rozpoczął debatę z ludźmi teatru, dziennikarzami oraz publicznością, w efekcie 
uzyskano kompromis, jakim jest powołanie na stanowisko dyrektora (od 2020 r.) René Pollescha - reżysera i autora związanego z Volksbühne w latach 2001-2007, gdy kierował sceną Prater.

\section{Wnioski}

Czy opisane wyżej przykłady świadczą o kryzysie publiczności? Jej aktywność, zaangażowanie, walka o własny teatr wymykają się z dotychczasowych kategorii statystycznych i wskaźników ekonomicznych. Jak zdefiniować pojęcie kryzysu publiczności teatralnej? Czy należy analizować liczbę sprzedanych biletów czy wykorzystanie miejsc na widowni?

Od lat odnotowywane jest zwiększenie liczby miejsc gry, czyli teatry poszukują nowych przestrzeni dla nowej, innej publiczności. Dziś także najbardziej znane niemieckie teatry podejmują takie wyzwania, właśnie po to, aby optymalizować swoją produkcję i bardziej precyzyjnie docierać do widza. We wrześniu 2019 roku została otwarta nowa scena, Neues Haus Berliner Ensamble, aby zdywersyfikować możliwości artystyczne zespołu oraz przyciągnąć nową publiczność, ponieważ w neobarokowej sali głównej tego teatru nie każdy może czuć się komfortowo.

Kryzys publiczności interpretuję więc jako pojęcie stymulujące rozwój oraz swego rodzaju ostrzeżenie przed zatraceniem równowagi między opcją opowiadającą się za sztuką i misją zwróconą w stronę widza. Jak pokazują wyżej omówione przykłady, widzom zależy na instytucji, ale ludziom teatru także, nikt nie będzie grał dla pustej widowni. Dlatego osiągnięcie kompromisu nie wydaje się trudne, zapewne każdy teatr go wypracuje albo już wypracował. Zgodnie z heterogenicznym charakterem niemieckiego systemu organizacji teatrów rozwiązań takich będzie wiele i będą się znacząco różnić.

W Niemczech przenoszenie pewnych schematów, modeli czy rozwiązań między ośrodkami jest trudne. Łatwiej pozwolić małym społecznościom tworzyć swoje własne modele i rozwiązania.

\section{Bibliografia}

Allensbach - Institut für Demoskopie Allensbach (1991), Kulturelles Interesse und Kulturpolitik. Eine Repräsentativumfrage über die kulturelle Partizipation, den Kulturbegriff der deutschen Bevölkerung und die Bewertung der Kulturpolitik, Allensbach.

Anheier H. (2015), Sechs Thesen zur Berliner Kulturpolitik von Prof. Dr. Helmut K. Anheier, https://www.hertieschool.org/fileadmin/2_Research/2_Research_directory/Resear h_projects/Berlins_cultural_policy_in_a_comparative_perspective/Sechs_Thesen zur_Berliner_Kulturpolitik.pdf [odczyt: 9.08.2019]. 
Dobijanka-Witczakowa O. oprac. (ca 1996), Goethe i Schiller o dramacie i teatrze. Wybór pism, Kraków: Wydawnictwo Uniwersytetu Jagiellońskiego.

Föhl P., Nübel D. (2016), Das Publikum öffentlicher Theater, [w:] P. Glogner-Pilz, P. Föhl (red.), Handbuch Kulturpublikum. Forschungsfragen und -befunde, Wiesbaden: Springer VS, s. 207-254.

Goethe J.W. (1953), Faust, tłum. E. Zegadłowicz, Warszawa: Państwowy Instytut Wydawniczy.

Haselbach D., Klein A., Knüsel P., Opitz S. (2012), Der Kulturinfarkt - Von Allem zu viel und überall das Gleiche. Eine Polemik über Kulturpolitik, Kulturstaat, Kultursubvention, Albrecht Knaus Verlag

Herrmann S. (2018), Mythos Publikum: Von Barrieren und Bedürfnissen, https://www.kiwit.org/ kultur-oeffnet-welten/positionen/position_6208.html [odczyt: 10.08.2019].

Janion M., Żmigrodzka M. (1998), Odyseja wychowania, Kraków.

Kulturfinanzbericht 2018 (2018), http://miz.org/downloads/dokumente/946/2018_Kulturfinanzbericht.pdf [odczyt: 10.08.2019].

Mandel B. (2016/2017) Audience Development, Kulturelle Bildung, Kulturentwicklungsplanung, Community Building. Konzepte zur Reduzierung der sozialen Selektivität des öffentlich geförderten Kulturangebots, https://www.kubi-online.de [odczyt: 9.08.2019].

Mandel B. (2013), Interkullturelles Audience Development, [w:] W. Schneider (red.), Theater entwickeln und planen, Kulturpolitische Konzeptionen zur Reform der Darstellenden Künste, Bielefed: Transcript Verlag, s. 137-152.

Prykowska-Michalak K. (2017), Do kogo należy teatr? Zmiany w teatrach Berlina, „Didaskalia”, nr 141.

Prykowska-Michalak K. (2018), Jak zniszczyć światowej klasy teatr przed upływem jednego sezonu? Fiasko pomystu Nowej Volksbühne, „Didaskalia”, nr 141.

Prykowska-Michalak K. red. (2016), System organizacji teatrów w Europie, Wydawnictwo: Instytut Teatralny im. Zbigniewa Raszewskiego, Warszawa.

Reckwitz A. (2017), Die Gesellschaft der Singularitäten. Zum Strukturwandel der Moderne, Berlin: Suhrkamp.

Schmidt T. (2017), Theater, Krise und Reform. Eine Kritik des deutschen Theatersystems, Wiesbaden: Springer VS.

Schmidt T. (2012), Theater-management: Eine Einführung (Kunst- und Kulturmanagement) VS Verlag für Sozialwissenschaften.

Theater und Theaterkritik in der Gesellschaft der Singularitäten (2018), https://theatermarginalien.com/2018/09/03/theater-und-theaterkritik-in-der-gesellschaft-der-singularitaeten/ [odczyt:10.08.2019].

Theaterstatistik, http://www.buehnenverein.de/de/publikationenundstatistiken/statistiken/ theaterstatistik.html [odczyt: 14.04.2019]. 